\title{
'It can't be found in books': how a flipped-classroom approach using online videos can engage postgraduate students in dissertation writing
}

\section{Jessica Clare Hancock}

City, University of London, UK

\begin{abstract}
This article explores action research that introduced a flipped-classroom approach to teaching dissertation writing. The cohort involved postgraduates studying at master's level, with a high proportion of international students. Dissertation writing had previously been taught in a lecture-based format, with limited time for activities. Moving some of the information-based content to online videos, which students were asked to watch before the teaching sessions, meant that face-to-face content could be entirely based around active learning and a social-constructivist approach. The students who experienced this flippedclassroom approach became more positive about the use of online videos during the teaching period. Many favourable comments were made about the videos, although several students appeared to prefer to use video content as a recap of face-to-face teaching, rather than appreciating a true flipped-classroom approach. Nevertheless, students agreed that the face-to-face activities helped put their learning from the videos into practice, the videos helped them to complete face-to-face activities, and that the teaching was beneficial for their dissertation writing abilities. Despite an absence of existing research for this context, a flipped-classroom approach to teaching dissertation writing is therefore recommended, as long as the students are fully briefed about the reasons for teaching in this way. This teaching method may be particularly beneficial for postgraduate students who are familiar with online learning through videos in earlier parts of their master's level courses.
\end{abstract}

Keywords: flipped classroom; dissertation writing; international students; postgraduate; videos; academic writing. 


\section{Introduction}

I carried out an action-research project into using a flipped-classroom approach for teaching dissertation writing at a London School of a post-1992 university. This School and campus predominantly has international students on taught postgraduate courses.

Students on all the School's master's programmes are required to undertake a dissertation module. As most of the students are unfamiliar with the academic literacies of UK HEIs in general, and their School in particular, this extended piece of writing $(12,000$ or 15,000 words) is often daunting. I initially taught dissertation writing through a series of hour-long lecture-based sessions, which were a mixture of information provision and small-group activities. However, there was not always sufficient time to cover the essential information that students needed nor to include tasks which would encourage students to take an academic literacies approach to their own writing.

An action-research intervention, therefore, was used to address these issues by taking a flipped-classroom approach. I chose this in the hope that it would allow students to revisit material, might increase student engagement and enable greater opportunities for active learning (James et al., 2014; Heyborne and Perrett, 2016; Zainuddin and Halili, 2016). I created five short (running time varied between 13 and 22 minutes) online videos with knowledge-based content and video-activities which students could re-watch, on-demand from any location. ${ }^{1}$ Using videos for information-based material left more time for active learning (such as discussing writing examples) within the face-to-face seminars, to help students to undergo the deeper learning required in a postgraduate dissertation (James, 1998). This article explores the findings of this action-research, to investigate the experience of introducing a flipped-classroom approach to support students in developing their dissertation writing abilities, and the use of online videos to engage students in their dissertation writing process. As student engagement is an over-determined concept (HEA, 2010), for this research I define engagement in the writing process as active participation in activities and becoming empowered to meet assessment requirements.

\footnotetext{
1 The videos and supporting materials (slides and scripts) are available from the Learn Higher website: http://www.learnhigher.ac.uk/writing-for-university/academic-writing/videos-to-develop-dissertation writing/ (Accessed: 20 August 2019).
} 


\section{Flipped classrooms}

The efficacy of traditional lectures to deliver learning outcomes has been questioned for some time, especially if they do not promote active learning or take account of differing abilities (Brown and Race, 2002). In response, a restructuring of student learning has been suggested, where knowledge transmission takes place before face-to-face contact, which can then include more active and deep learning (Hao and Lee, 2016). In the last decade, this approach has been described as a flipped classroom and has begun to be more widely used and investigated (Strayer, 2007). A flipped classroom involves students completing work before class to gain information which is used to complete activities during the face-to-face session (Abeysekera and Dawson, 2015); it is an overturning of a more traditional approach where knowledge is transmitted in class and practised afterwards in individual activities. Although some researchers still accept a wide definition of pre-class tasks (so would include preparatory reading; see, for example, O'Flaherty and Phillips, 2015), many argue that the term 'flipped classroom' should only be used when the pre-class activities involve online learning (Staker and Horn, 2012) and, in particular, watching instructional videos (Zainuddin and Halili, 2016; Zuber, 2016). As research indicates that students prefer viewing videos to reading (Sahin et al., 2015), this specific definition is more appropriate for this paper, which aims to examine how students can be engaged in their dissertation writing process.

Some clear benefits of a flipped-classroom approach have been argued for in the literature. Students have reacted positively (James et al., 2014), particularly to the ability to revisit videos (Heyborne and Perrett, 2016). Moreover, Huang and Hong (2016) report that discussion participation rises and Zainuddin and Halili's (2016) meta-analysis states that student motivation is frequently improved. An interesting outcome noted by Lage, Platt and Treglia (2000) was the particular applicability of benefits to female students. Some studies demonstrate improved learning outcomes (Berg et al., 2015; Kurt, 2017; Wasserman et al., 2017). Yet the evidence for increased assessment scores is mixed, with other research showing no change (Galway et al., 2014) and Blair et al. (2016) observing that a flipped classroom led to fewer higher-level marks, possibly due to decreased attendance. Indeed, Comber and Brady-Van den Bos (2018) also discovered that it caused attendance issues and recommend that the pedagogical reasoning should be explained to students (Wang and Qui (2018) similarly advocate for providing support for students to master this new kind of learning; they also note that there is a lack of literature examining negative student 
perceptions of flipped classrooms, and that the significant factor for learning is what is done in the face-to-face sessions.

These arguments indicate that the enthusiasm for a flipped-classroom approach expressed in the research literature may not be fully supported by learning gains for students. Another disadvantage of a flipped-classroom approach described by many researchers is the additional time required to produce videos (Schlairet et al., 2014; Moran and Milsom, 2015). Herreid and Schiller (2013) suggest sourcing existing videos, but their quality is variable. It is also likely that students would not perceive external videos as authoritative, unlike videos presented by an existing lecturer (Bergmann and Sams, 2012). Accordingly, I chose to create my own videos.

In a secondary-school context, Bergmann and Sams (2012) make the important point that 'pedagogy should drive technology' (p. 21) and argue that what is needed is not just videos to be viewed before face-to-face sessions, but a concept which they call flipped mastery - enabling students to take advantage of different ways of learning (text books, videos, the internet) to progress at their own pace through differentiated tasks. The classroom thus becomes a space where students benefit from a personalised approach, being assessed (often by computer marking) when they feel ready. Despite the attractiveness of creating this kind of environment, due to the nature of teaching writing (which will be discussed later), the limited face-to-face time available (four hours of class time), the non-adjustable submission dates and requirements for the dissertation assessment, and the extensive use of peer discussion activities, I did not feel that this was possible in my context.

The main issue with a flipped-classroom approach appears to be convincing students of the requirement to view the videos (Boevé et al., 2016). Indeed, Pienta (2016) emphasises that a flipped classroom will not automatically solve student problems or increase engagement. However, Gilboy et al. (2015) indicate that students are more receptive once they become accustomed and realise the benefits; nevertheless, they recommend that student endorsement should be obtained early on. Brunsell and Horejsi (2013) assert that students need to be tested regularly to prove that they are viewing the material, but, as Slomanson (2014) argues, this does not respect students' autonomy, something that was especially important as I was teaching postgraduate students who are experienced 
learners. Furthermore, as the School's dissertation students are from a range of programmes, it would be difficult to alter their assessments to include in-course tests. Instead, Schwartz (2014) maintains that students are able to self-regulate and will increase their pre-class efforts if they realise they are behind their peers during group work. Additionally, Davis (2016) and Gilboy et al. (2015) advocate clearly explaining the benefits and expectations of the flipped classroom, to encourage student support. Doing so may also negate the feedback received in Wasserman et al.'s (2017) study, where students objected to active rather than passive learning during classes. Furthermore, Schmidt and Ralph (2016) advise that interactivity also increases the likelihood of students completing the work, whilst Nematollahi et al. (2015) indicate that students' attention spans necessitate videos shorter than twenty minutes; Bergmann and Sams (2012) suggest a minute per high-school grade but it is not clear how this would translate to HE. Consequently, I ensured that my five videos were interactive and a suitable length (13-22 minutes), and explained the purposes of the flipped-classroom approach to the students (although, as discussed further in the results section, on reflection this could have been done more effectively).

\section{Teaching academic writing}

Writing development is a nascent discipline, which has progressed from remedial actions to empowering students to understand the conventions of written academic discourses (Englert et al., 2006). Lea and Street's (1998) academic-literacies approach establishes that academic writing cannot be described by generic rules; instead, students should be made aware of the socially-constructed nature of the requirements of their own contexts (Comber and Simpson, 2001). Similarly, Freire (1972) explores the imperative to teach writing as a creative process, rather than a set of instructions. As students' backgrounds differ greatly, especially at the School involved in this project, and academic writing varies between subjects, levels, institutions and countries (Flowerdew, 2000; Foster and Russell, 2002), writing development needs to explore ways of decoding literary practices, and ensure that students possess the knowledge assumed by assessment setters. Smidt (2009) argues that the process of teaching writing therefore needs to be dialogic, and Lavelle (2009) contends that modelling (examining examples of work by other students) is also an essential component of comprehending academic discourses. Writing development thus inherently requires a social-constructivist approach to knowledge, and 
for students to be given opportunities to discuss and practise their own meaning-making; Beal (1993), Allal et al. (2005) and Wagner (2016) demonstrate the efficacy of peer collaboration to revise and improve writing. As such, writing development has particular demands to provide opportunities for active and collaborative learning as well as knowledge transmission.

\section{Flipping the writing classroom}

A flipped-classroom approach consequently seems suited to writing development which requires a shared foundation of concepts (such as expected content in a particular dissertation chapter) but also socially-constructed learning. Despite the suitability of this teaching method, few studies have investigated a flipped classroom strategy in writing development; most literature examines a more fact-based scientific context. Nevertheless, Campbell (2016) argues that a flipped classroom provides business-writing students with a better appreciation of concepts. However, Hall and Dufrene (2016) note that although videos can deliver more academic-writing information to students, class time must be dedicated to checking students' understanding, especially as some students do not complete pre-class activities. Indeed, Engin and Donaci (2014) reveal that, although students enjoyed academic-writing videos, they desired continued face-to-face dialogue with lecturers. Thus, I began seminars by asking students to re-cap the video information and allowed time for questions.

As the research on flipping an academic-writing classroom demonstrates increased active learning and a more enjoyable process (Hall and Dufrene, 2016), it is likely to be a beneficial way of engaging dissertation students with their writing process. Videos will also provide some writing-development teaching to off-campus students (students from the School often returned to their countries of origin during the dissertation period). As research in this area is limited (and none addresses dissertation writing or a postgraduate context), this paper will provide a valuable insight into students' experiences and the efficacy of a flipped postgraduate dissertation writing approach.

\section{Methodology}


Action research was used to allow me to both make and analyse a change to my teaching. Action research began to be clearly theorised in the mid-twentieth century as directly involving social action (Lewin, 1946). Although precise definitions vary, it is agreed that action research is a 'practice-changing practice' (Kemmis, 2009, p. 465); it entails a researcher modifying a situation and reflecting on the results of this alteration in a cyclical process, which is particularly applicable to continually-changing educational contexts (Morton-Cooper, 2000; Herr and Anderson, 2005). The most significant benefit is the amalgamation of educational research and practice (Norton, 2009); other methodologies are often criticised as establishing findings that are either not of concrete value, or which are rarely employed in teaching (Pine, 2009). In contrast, a practical application is an inherent aspect of action research (Coghlan and Brannick, 2005), which always aims to create an improvement (Kember, 2000). Nevertheless, Vaughan and Burnaford (2016) state that action research can be seen as more subjective than other methodologies; it cannot involve a true experimental design, and so results such as higher assessment scores may be caused by confounding factors. Yet this article does not aim to demonstrate a causal effect on learning outcomes, but instead analyse students' experiences of a flipped classroom. Furthermore, there is nothing in action research that necessarily entails a lack of applicability or rigour (Norton, 2009). The data is likely to be pertinent to other settings where lecturers are considering a flipped classroom for academic-writing teaching (Elliott, 2009). Indeed, this approach has been informed by existing research which has identified potential pitfalls, such as video length (Nematollahi et al., 2015).

Action research is especially relevant to this project because of its political aspects, given its potential for critiquing existing systems and demonstrating possibilities for change; similarly, writing development is fundamentally concerned with social justice, emerging from a focus on widening participation in HE for students from non-traditional backgrounds (Orr, 2005; Lillis, 2006). Within education, action research can easily align with objectives to challenge existing teaching methods and approaches, to become critical actionresearch (Xiao et al., 2012). Thus, it can deliver clear benefits, not only by offering new ways of addressing the learning requirements of students, but also by delivering positive benefits to lecturers through empowering them to make changes (Hine, 2013), thereby creating a 'knowledge democracy' (Pine, 2009, p.55) and interrogating existing thinking about learning (Perrett, 2003). Action research, therefore, supports the desire to improve 
the learning experiences of students and provides a more systematic way of reflecting on how teaching can be adjusted to acknowledge the needs of different kinds of students.

Considerations were given to relevant ethical issues during this study, and ethical approval was obtained from my institution. Accordingly, participants were provided with full information about the study and their consent was sought to take part, and they completed the questionnaires anonymously. I made sure I emphasised that their participation or nonparticipation would not affect their dissertation mark or the support I provided in any way, and that their comments would be used in a way which would not identify them. Participants were also informed that they could withdraw, without giving a reason, at any time before data analysis commenced.

\section{Teaching}

My previous dissertation writing teaching involved four hour-long face-to-face lecturebased sessions with included activities. Although the research on using a flippedclassroom approach to teach writing was limited, the evidence indicated that students would benefit from this approach (Hall and Dufrene, 2016). The flipped-classroom approach entailed producing five videos, using Camtasia to create narrated screencasts. Writing cannot be reduced to the ability to follow a list of instructions, as it requires awareness of the obligations of contexts (Lea and Street, 1998; Comber and Simpson, 2001). Thus, to enable a socially-constructivist approach, and to use interactivity to increase student use (Schmidt and Ralph, 2016), I designed video learning-activities so students could participate in dialogues about dissertation writing, such as using Padlet (an online noticeboard) to discuss summaries of their main findings. This also meant that, although students were likely to view the videos alone, they would not feel isolated (Wei and Chen (2012) note that this is a common issue with online learning) as most tasks allowed them to see other students' responses and learn from peers (Allal et al., 2005). The videos had an additional advantage of on-demand availability, when the content became relevant, and meant that students who could not attend campus seminars could still have some teaching, although they would miss out on valuable learning opportunities from the face-to-face sessions. 
The face-to-face time involved an active and socially-constructed learning environment that was designed to be more engaging to students and encourage attendance. Several activities allowed students to learn through examining other writing, as such modelling is beneficial (Lavelle, 2009). Students would discuss the strengths and weaknesses of writing excepts in small groups, enabling less confident students to participate in unintimidating peer-dialogues rather than a whole group discussion (Barkley, 2010). The writing samples showed students what elements mentioned in the video (such as clarity) looked like in practice. After students evaluated the writing excerpts in small groups, I led a whole-group conversation to share different responses. This dialogue enabled students to benefit from further peer collaboration and to see the contextually and socially-constructed nature of writing requirements (Allal et al., 2005). I also provided feedback about my assessment of the writing, thereby increasing their knowledge of appropriate ways of meeting the dissertation requirements (Flowerdew, 2000). I also used learning technology to increase participation; for example, in one seminar I asked students to post activity responses on a Padlet wall as this might be easier than contributing vocally for some students (Hew and Cheung, 2012). It also meant that students could learn from each other's answers and my assessment of and feedback on other students' work as well as their own (Markett et al., 2006).

\section{Data analysis}

Data was collected at two points:

- Questionnaire 1 (Q1): paper questionnaire given out during the first face-to-face seminar: this covered students' initial responses to videos.

- Questionnaire 1 (Q2): paper questionnaire given out during the final seminar, with an online version emailed afterwards to all relevant students: this covered students' concluding responses to the videos and face-to-face seminars.

This approach was used to maximise the response rate (historically, attendance for the final session has been low, and online responses are often poor (Crawford, 2014)) and to offer insight into whether students' opinions change as they become more used to the approach. Statistical analysis was used for the quantitative survey data (Teo, 2013), and a 
thematic analysis for the qualitative survey data (Mertens, 2015). Some Q1 questions were repeated in Q2 to allow for direct comparison. Due to lower attendance at the final seminar, fewer responses were gathered. 46 students took a dissertation module during the action-research period. Nineteen students ( $41 \%$ of the cohort) answered Q1, and eight students (17\% of the cohort) answered Q2 (three online, five paper). Students' self-report data was triangulated with published research and my observations of the seminars. The questionnaires gathered quantitative data, mainly measured using Likert-type scales, and qualitative data from open-ended questions. As both questionnaires were completed anonymously, changes in the data from specific students cannot be tracked.

\section{Findings}

\section{A. How can a flipped-classroom approach be used to support students in developing their dissertation writing abilities?}

The main teaching alteration for the flipped-classroom approach was providing initial information through online videos. Therefore, students were asked whether they would prefer to be taught in that format, or through a lecture (as was previously the case). In Q1, the modal response was a strong preference for lectures with the median response a slight preference for lectures. In Q2, the modal response had changed to no preference and the median response was between a slight preference for lectures and no preference. The distribution of answers can be seen from Figure 1, with no student expressing a strong preference for video delivery in either Q1 or Q2:

Figure 1. Comparison of initial preferences (Q1) and final preferences (Q2). 


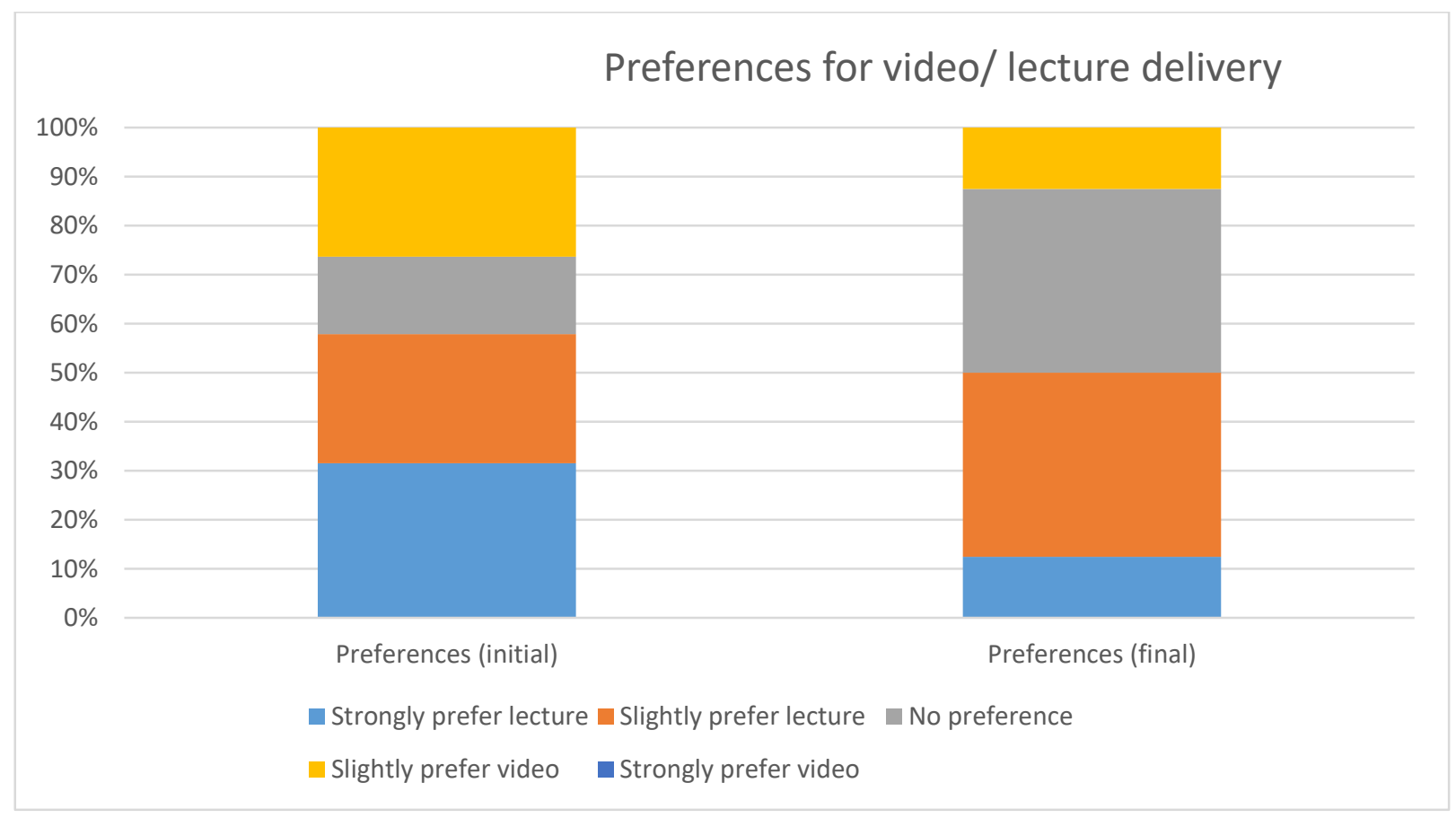

Nevertheless, an unpaired t-test showed that the differences between questionnaires was not statistically significant $(P=0.79)$, due to the small and reduced sample size for the $Q 2$. It does, however, suggest that students might have appreciated video delivery more as they became familiar with this method, supporting Gilboy and Pazzaglia's (2015) research. Yet this was not true for all students, one of whom commented in Q2 they could 'understand better' in a lecture, echoing Q1 students who preferred face-to-face delivery for the ability to 'ask questions'. Indeed, one student said: 'I think video . . . can be limiting to the learning experience - it ... doesn't allow for interaction' (Q1). This might reflect the learning context of the School in his research, where students are rarely taught in large groups; students who experience less interactive teaching in big lectures may have reacted differently. A comment about face-to-face teaching being 'more personal' (Q1) indicates that Herreid and Schiller's (2013) suggestion to source existing videos would be even less successful; this indicates that bespoke videos are necessary for the design of an effective flipped-classroom approach. Further discussion of the usefulness of videos is provided in part $b$ ) of this Findings section.

Still, some students indicated that they had no clear preference of lecture or video as 'both are good' (Q1). Students also described the advantages of videos, noting that 'I can watch it whenever I want' (Q2), 'you can repeat it if you don't understand something' (Q1), and that the videos could be accessed 'any time' (Q1). These responses accord with Heyborne and Perrett (2016) who include repeat viewings as a clear benefit. Yet, one student's 
comment is perhaps telling, as they stated: 'I think both are necessary! Videos can act as a "refresher" . . . face to face allows for interaction' (Q2). Although this student valued the videos, they referred to their function of reinforcing content, rather than a flippedclassroom approach where a video introduces information which is used during an activelearning seminar. Indeed, another student's reason for recommending the videos was 'that [they are] useful, especially if you missed the [seminar]' (Q2). This accords with my experience within the seminars, where a minority of students had not understood the requirement to view the video beforehand. Davis (2016) argues that a flipped-classroom approach should be introduced carefully to students to clarify the expectations and the pedagogical justification. However, for this action research project, the first seminar was part of the dissertation induction, meaning that the instructions about viewing the videos were given via email which was not conducive to creating a dialogic exchange with the students about this new pedagogical approach. This problem with student understanding supports other findings that extensive consideration should be given to engaging students with a flipped-classroom approach (Gilboy et al., 2015). Indeed, the initial questionnaire demonstrated that only $33 \%$ of the students had previously learnt through videos. Furthermore, those previous videos were designed to be used as an extra resource rather than in a flipped-classroom approach, emphasising the novelty of this method of instruction. The findings clearly illustrate the need to achieve student comprehension of pedagogical choices.

When asked about the face-to-face seminars, the modal and median responses indicated that they found the class activities very useful (Figure 2), and that the seminars had made them slightly more engaged in the dissertation writing process (Figure 3).

\section{Figure 2. (from Q2)}




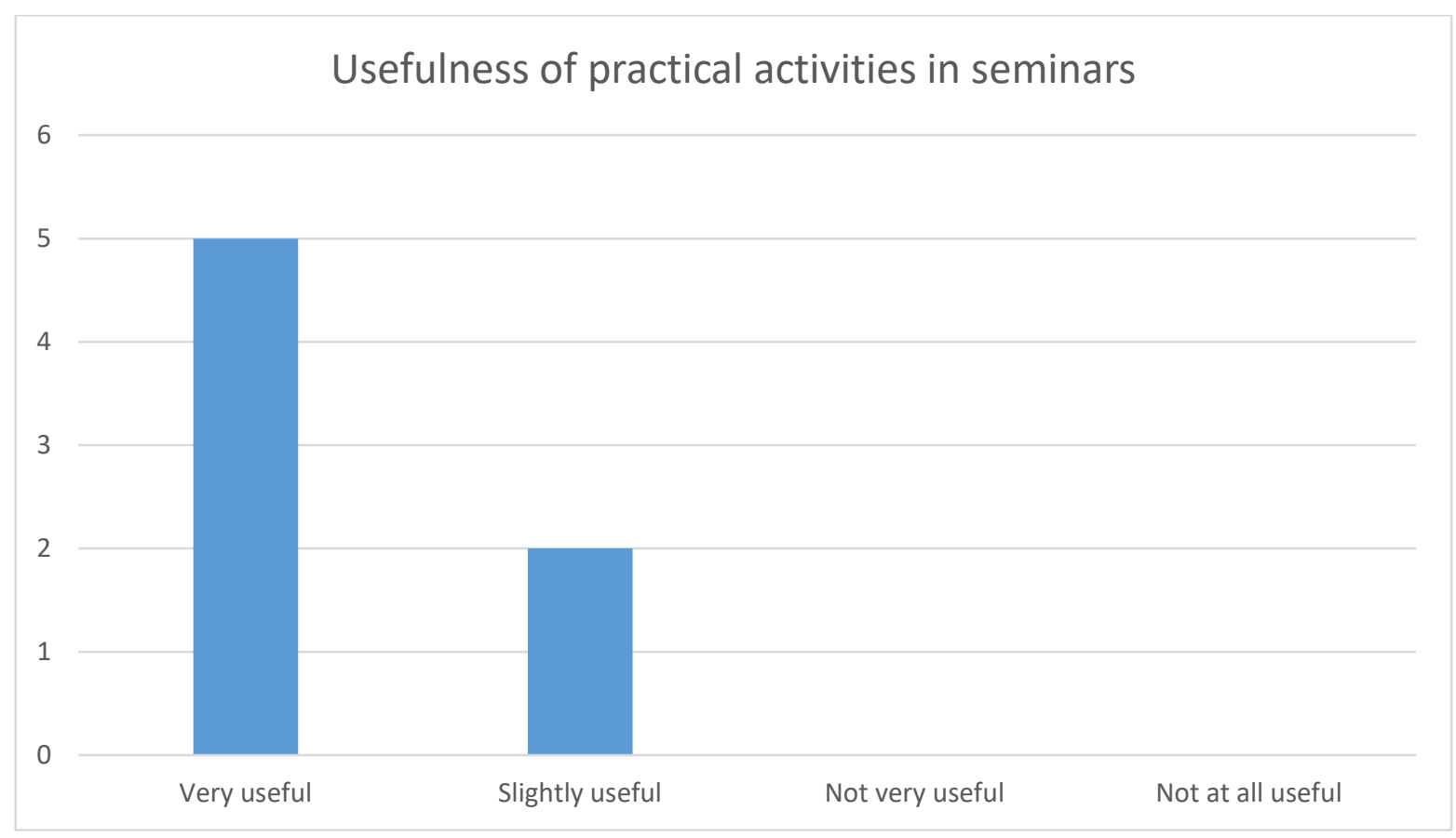

Figure 3. (from Q3)

Did the classes help you feel more engaged in the dissertation-writing process?

4

3

1

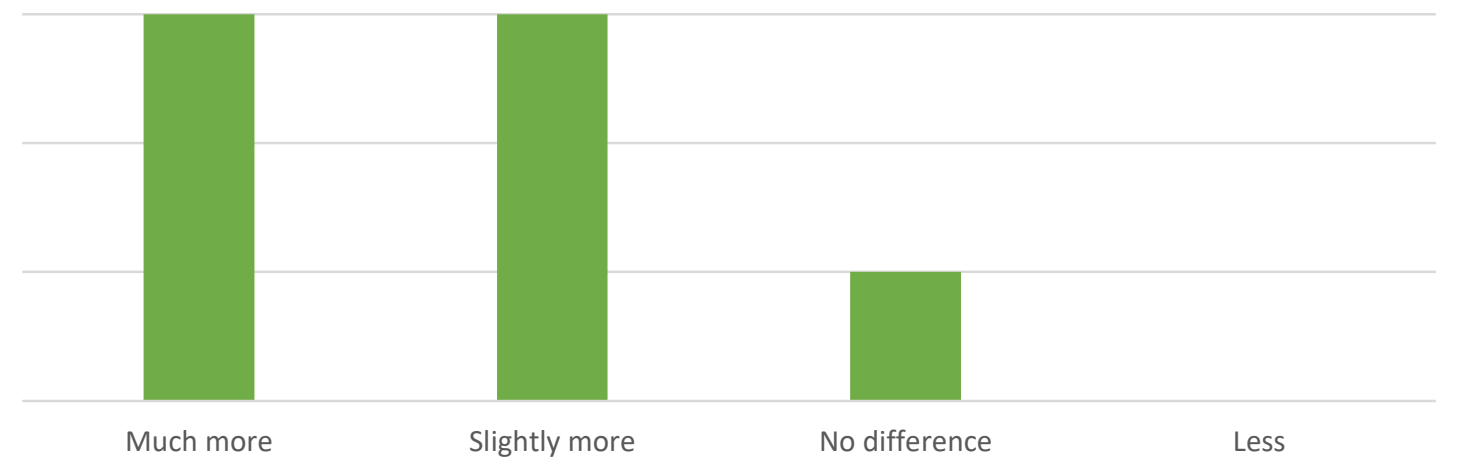

These results indicate that students did find the design of the seminars to focus on practical activities beneficial to their dissertation writing abilities and somewhat engaging. Furthermore, all of the students found that the activities had allowed them to put their learning from the video into practice, that the videos had helped them complete the activities (which corroborates my seminar observations), and would recommend the classes to other students. This suggests that, by the end of the teaching at least, students were able to see the benefits of watching the videos before seminars, thus alleviating the key issue identified by Boevé et al. (2016). These results also support Huang and Hong's 
(2016) findings that a flipped-classroom approach increased student participation in faceto-face activities. Comments on the seminars included that the 'activities make for a realistic "taster" of what you will be writing in your dissertation' (Q2) and that they were 'very useful' (Q2); this endorses other research which reveals student satisfaction with flipped-classroom approaches (James et al., 2014). Wasserman et al. (2017) indicate that some students objected to more active learning, but this does not seem to have occurred and I observed that students were engaged and enjoyed the activities. The responses indicate that students did benefit from the flipped-classroom approach, as the seminar activities enabled the use and application of knowledge from the videos. Nevertheless, more could have been done to assist students in transitioning to this novel teaching method.

\section{B. How can online videos be used to engage students in their dissertation writing process?}

Not all students accepted video delivery as a replacement for lectures, but most saw the benefits of videos as an additional resource. Responses to the final open-ended question in Q1 included: 'I enjoy [the videos]', 'keep [the videos] coming', 'please arrange more video[s] like this' and 'the pace of the person speaking was perfect and it was very clear. The videos were made pretty well!'. Although students were clear that they valued face-toface teaching, they also benefitted from the videos. Both the modal and median responses in Q1 show that students thought the videos were the correct length and that information was pitched at the right level. In Q1 and Q2 the modal and median responses were that students found the content very useful (Figure 4), and that there were the right number of activities (Figure 5).

Figure 4. Comparison of initial response to videos (Q1) and final response (Q2). 


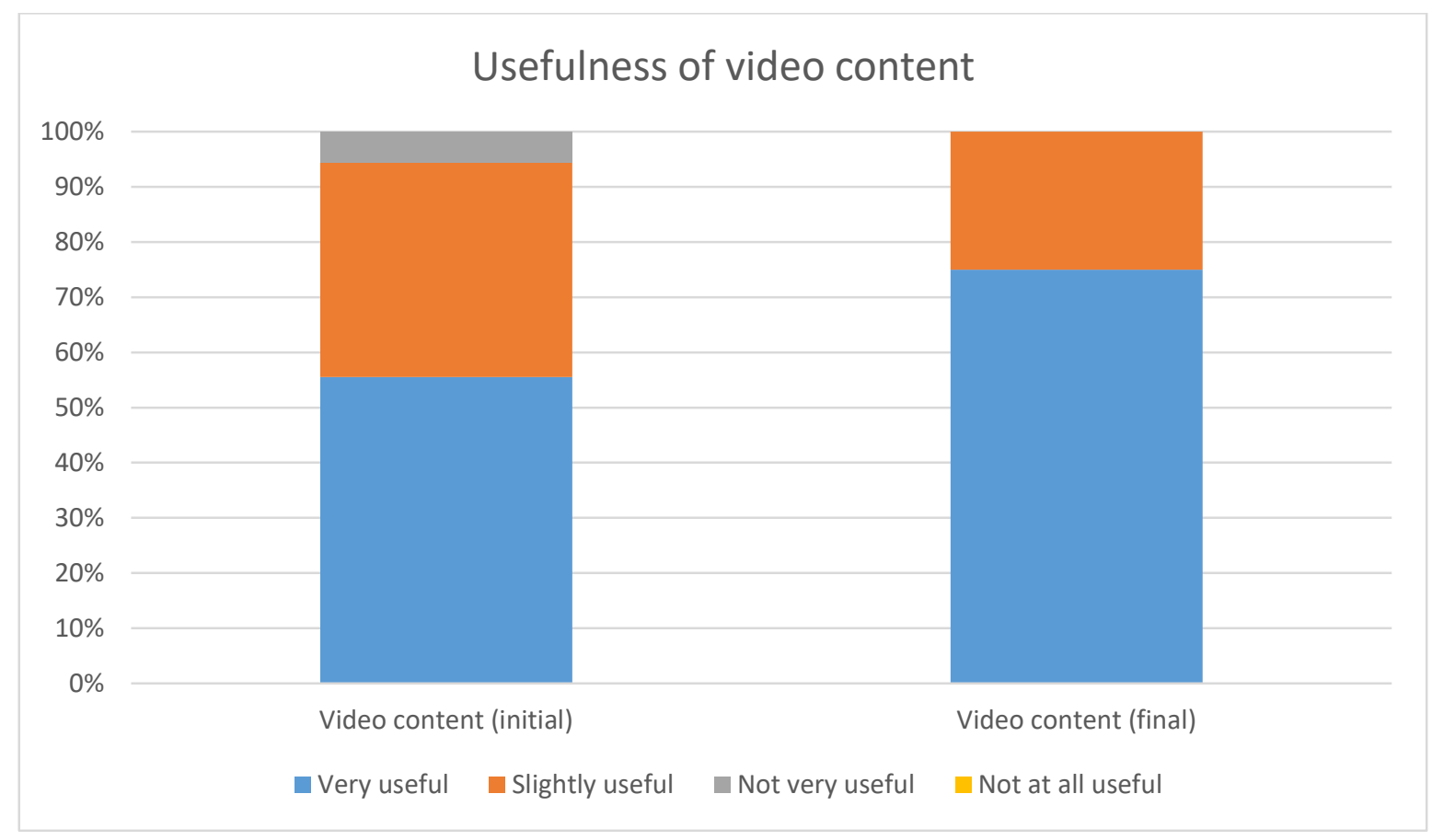

Figure 5. Comparison of initial response to videos (Q1) and final response (Q2).

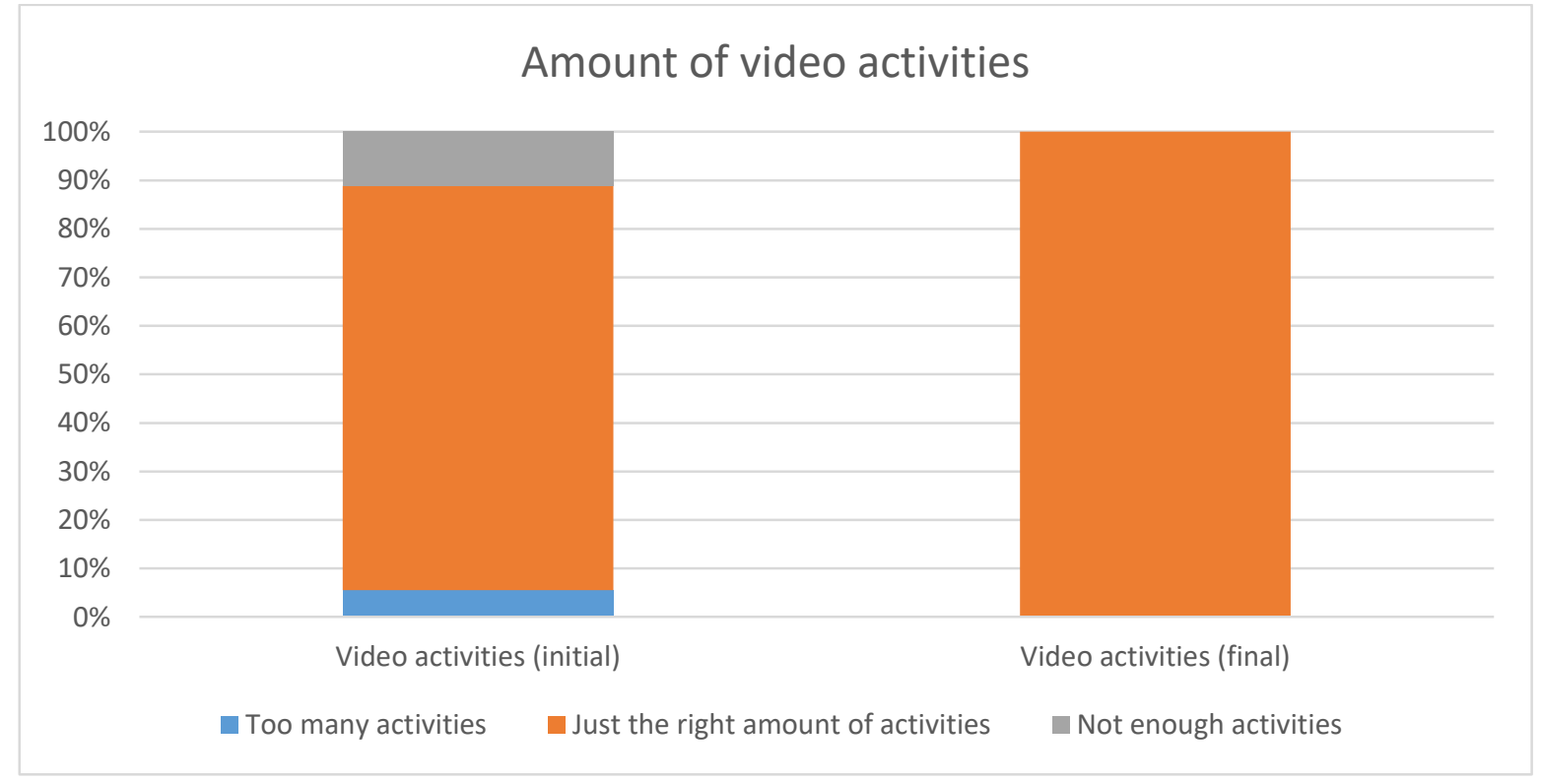

In Q1, 88\% of students stated that they would watch the videos again, which altered to $75 \%$ in Q2 (probably because students were towards the end of their writing period, or might have already submitted). In Q1, 89\% of students stated that they would recommend the videos to other students, which rose to $100 \%$ in Q2. Q2 findings showed that the videos made students feel more engaged in the writing process (Figure 6).

\section{Figure 6. (from Q2)}




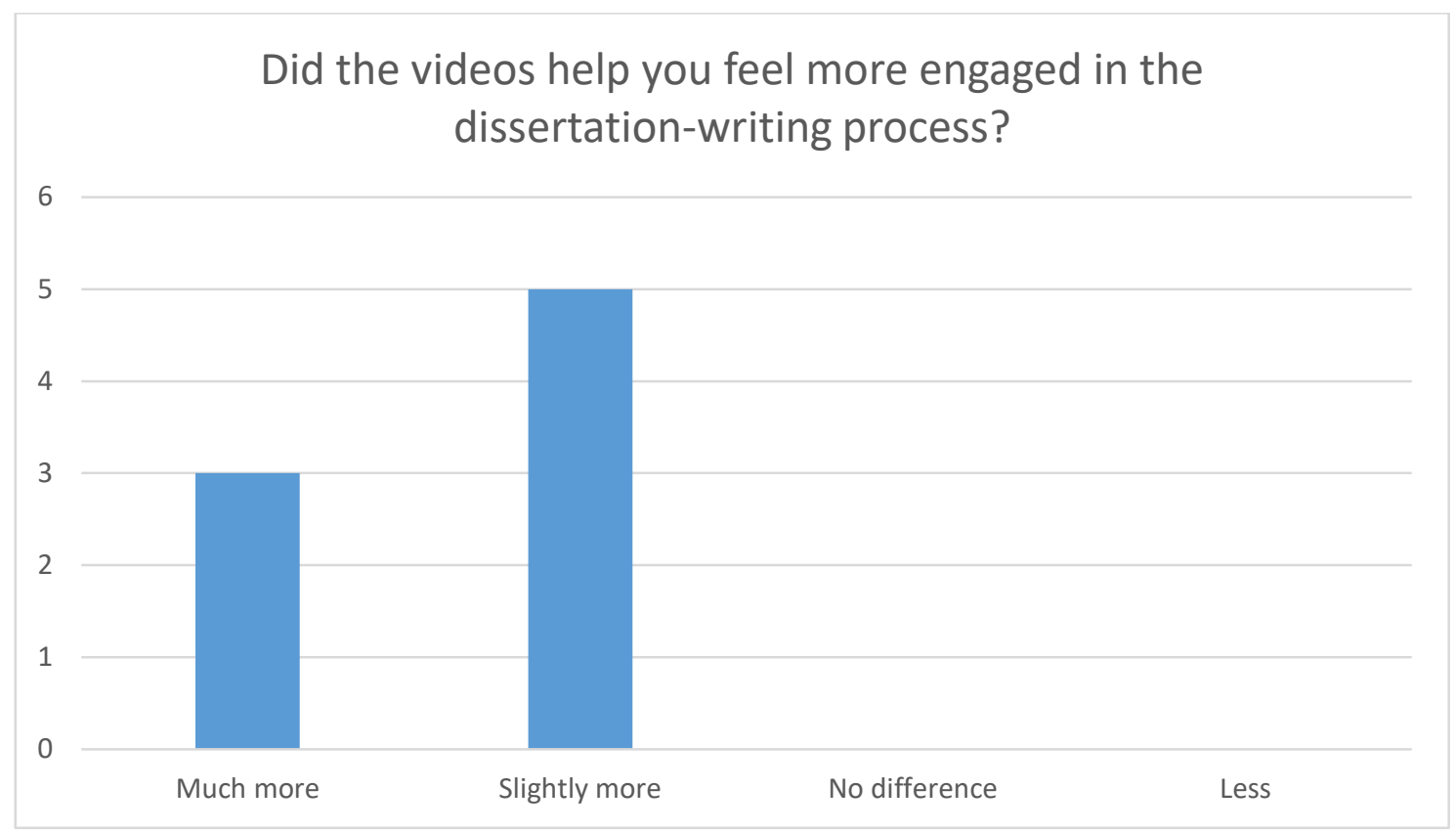

These results demonstrate that the videos increased student engagement more than the seminars. This is reflected in the positive comments about the videos.

In Q1, one student commented that they 'really liked the schedule creator', indicating that they had benefitted from the activities within the video, reinforcing Schmidt and Ralph's (2016) contention that interactivity is necessary. Another student answered that: 'the little key points ... were very helpful and it can't be found in books' (Q1). This indicates that unique information was particularly valued and that the videos were seen as more useful than existing written material, corroborating the findings of Sahin et al. (2015). In Q2, one student even referred to the videos as 'must watch'. This overall enthusiasm must be treated with a note of caution, however, as the students who chose to answer Q1 and, especially, Q2 may have been keener than other students who were not represented in the research: particularly considering the response rate as $41 \%$ of the cohort answered Q1 and $17 \%$ of the cohort answered Q2. Nevertheless, the design of the videos to be relatively short, interactive, and with content that was clearly aligned to the assessment was successful in engaging students in their dissertation writing process. The videos were perhaps particularly helpful in my context, when teaching many international students with English language issues who may not always wish to refer to written information; videos also allowed students to re-watch the information, and to view at their own pace to ensure they understood the content. 


\section{Conclusion}

The questionnaire responses demonstrate that students enjoyed the videos and that the content, amount of activities, level of information and length were designed correctly and were successful in engaging students in their dissertation writing process. Students particularly liked their repeatability and interactivity. Yet, it is less clear that students felt that they benefitted from a flipped-classroom approach. It was not adequately explained to students that the videos were a replacement for lecture-style information delivery, and that providing the videos would allow for more interaction and active learning during the faceto-face seminars (Gilboy and Pazzaglia, 2015). Many students would have liked the information from the videos delivered face-to-face, and to have used the videos to revise information. The findings emphasise the need to prepare students more fully for flipped classroom teaching, especially when it is new to them (Davis, 2016). Although the research evidence suggested that one of the main issues with a flipped-classroom approach is persuading students to view the videos, this was not fully considered (Boevé et al., 2016). Ensuring that seminar delivery included time at the beginning to communicate the reasons for this approach is likely to have made the teaching more effective (Gilboy et al., 2015). Nevertheless, students appreciated the seminar activities and the social-constructivist approach made them engaged in their writing process; this provided benefits to students who participated, as I observed an increased understanding of dissertation writing literacies by the end of each session. An additional benefit of the flipped-classroom approach was that, although the seminars continued to be attended by a minority of students, non-attendees could at least experience some of the teaching through the videos.

Learning Development colleagues, therefore, are likely to find aspects of my approach beneficial for dissertation writing teaching, particularly as this is an assessment which many students find difficult. No previous research has addressed the use of a flipped classroom for teaching dissertation writing; this small-scale action research has investigated some of the advantages and issues, which would profit from further exploration through wider use in other institutions, particularly those with different kinds of students. Although this paper addressed a solely postgraduate context, a flippedclassroom approach to develop the dissertation writing ability of other kinds of students in Higher Education is likely to be similarly beneficial. 


\section{Recommendations}

Despite the small and self-selecting sample, the results illustrate both the benefits and problems with this approach. The responses to my research also provide a salutary lesson in the importance of fully explaining a flipped-classroom approach to students for any colleagues who wish to use this method. Furthermore, some students did not appear to appreciate the flipped-classroom approach, and several seemed to misunderstand the point of the videos (viewing them as ways to re-visit information rather than receive information for the first time). In retrospect, it was particularly challenging for students to experience a new teaching method at the end of their programme. A flipped-classroom approach for dissertation writing may have been better received if students had become used to this method earlier in their courses; it is likely that they would have been more receptive to new methods at the beginning of their master's degrees. Indeed, as many of the students have not previously studied in the UK before, they are already making significant adjustments to the ways in which they learn at university. Requiring them to adapt to a flipped-classroom approach for the teaching for their final assessment may have been overwhelming. I recommend, therefore, using videos to teach writing at an earlier stage by using videos as an additional resource, to allow students to become accustomed to blended learning. A flipped-classroom approach, with a full explanation, could then be gradually introduced, perhaps for one seminar, to enable students to adjust, before experiencing a full flipped-classroom approach for dissertation writing.

I would also recommend initiating conversations with students about the flipped-classroom approach during face-to-face seminars, to gain some immediate feedback and to explore the reasoning for using it. This is also likely to make the students feel more involved in their own learning and allow them to consider what teaching methods they prefer and their own learning journey. Additionally, a recorded webinar could be used to explain the benefits and purposes of a flipped-classroom approach, so that students could discuss and review this information whenever they needed to; providing online teaching about the benefits of the seminars might entice more students to attend seminars, even if they are initially reluctant to travel to campus during their dissertation writing period. 
There is currently insufficient research addressing the flipped-classroom approach for teaching academic writing. As with much action research, this project has provided some preliminary indications of the usefulness of this teaching method, but further work is needed. This particularly needs to look at the benefits of different kinds of resources - I used screencasts as I was already familiar with this method, and it was practical within the time I had, but other video or resource types may be more effective. I did not feel able to explore a flipped mastery style classroom, as advocated by Bergmann and Sams (2012) where students are able to progress and be assessed at their own pace, due to the constraints of the dissertation assessment and the time available, but this would be valuable to investigate in a writing context, particularly as this area is so different from the more knowledge and fact-based science teaching context of Bergmann and Sams. Taking an academic literacies approach to writing means that modelling and peer discussions are invaluable in teaching, and so an exploration of how this could be achieved in a flipped mastery method would be productive. This study has indicated the potential for a flipped approach to teaching writing; it is my hope that it inspires further research into how this might be utilised effectively.

\section{References}

Abeysekera, L. and Dawson, P. (2015) 'Motivation and cognitive load in the flipped classroom: definition, rationale and a call for research', Higher Education Research and Development, 34(1), pp. 1-14.

Allal, L., Mottier, Lopez, L., Lehraus, K. and Forget, A. (2005) 'Whole-class interaction in an activity of writing and revision', pp. 69-91, in T. Kostouli (ed.), Writing in context(s): Textual practices and learning processes in sociocultural settings. Boston: Springer.

Barkley, E.F. (2010) Student engagement techniques: a handbook for college faculty. San Francisco: Jossey-Bass.

Beal, C. R. (1993) 'Contributions of developmental psychology to understanding revision: Implications for consultation with classroom teachers', School Psychology Review, 22, pp. 643-655. 
Berg, A.L., Ibrahim, H., Magaster, S. and Salbod, S. (2015) 'Flipping Over the Flipped Classroom', Contemporary Issues in Communication Science and Disorders, 42, pp. 16-25. Available at:

https://www.asha.org/uploadedFiles/ASHA/Publications/cicsd/2015S-Flipping-Overthe-Flipped classroom.pdf (Accessed: 20 August 2019).

Bergmann, J. and Sams, A. (2012) 'Flip your classroom: Reach every student in every class every day', Washington, DC: International Society for Technology in Education. Available at http://i-lib.imu.edu.my/NewPortal/images/NewPortal/CompEBooks/Flip-Your-Classroom.pdf (Accessed: 20 August 2019).

Blair, E., Maharaj, C. and Primus, S. (2016), 'Performance and perception in the flipped classroom', Education and Information Technologies, 21(6), pp. 1465-1482.

Boevé, A.J., Meijer, R.R., Bosker, R.J., Vugteveen, J., Hoekstra, R. and Albers, C.J., (2016) 'Implementing the flipped classroom: an exploration of study behaviour and student performance', Higher Education, 74, pp. 1015-1032. Available at: https://link.springer.com/content/pdf/10.1007\%2Fs10734-016-0104-y.pdf (Accessed: 20 August 2019).

Brown, S. and Race, P. (2002) Lecturing: a practical guide. London: Kogan Page.

Brunsell, E. and Horejsi, M. (2013) 'A flipped classroom in action', The Science Teacher, $80(2)$, p. 8.

Campbell, K.S. (2016) 'Flipping to teach the conceptual foundations of successful workplace writing', Business and Professional Communication Quarterly, 79(1), pp. 54-67.

Comber, B. and Simpson, A. (2001) Negotiating critical literacies in classrooms. Mahwah, NJ: Lawrence Erlbaum Associates. 
Comber, D.P.M. and Brady-Van den Bos, M. (2018) 'Too much, too soon? A critical investigation into factors that make flipped classrooms effective', Higher Education Research and Development, 37(4), pp. 683-697.

Coghlan, D. and Brannick, T. (2005) Doing action research in your own organization. $2^{\text {nd }}$ edn. Thousand Oaks, Calif; London: SAGE.

Crawford, M. (2014) Developing as an educational leader and manager. London: Sage.

Davis, N.L. (2016) 'Anatomy of a flipped classroom', Journal of Teaching in Travel and Tourism, 16(3), pp. 228-232.

Elliott, J. (2009) 'Building educational theory through action research' in Noffke, S.E. and Somekh, B. (eds.) The SAGE handbook of educational action research. Los Angeles, Calif.; London: SAGE.

Engin, M. and Donanci, S. (2014) 'Flipping the classroom in an academic writing course', Journal of Teaching and Learning with Technology, 3(1), pp. 94-98.

Englert, C. S., Mariage, T. V. and Dunsmore, K. (2006) 'Tenets of sociocultural theory in writing instruction research', pp. 208-221, in MacArthur, C. A., Graham, S. and Fitzgerald, J. (eds.) Handbook of Writing Research. New York: Guilford.

Flowerdew, J. (2000) 'Discourse community, legitimate peripheral participation, and the nonnative-English-speaking scholar', TESOL Quarterly, 34(1), pp. 127-150.

Foster, D. and Russell, D. R. (2002) Writing and learning in cross-national perspective: Transitions from secondary to higher education. Mahwah, NJ: NCTE and LEA.

Freire, P. (1972) Cultural action for freedom. Harmondsworth: Peguin.

Galway, L.P., Corbett, K.K., Takaro, T.K., Tairyan, K. and Frank, E. (2014) ‘A novel integration of online and flipped classroom instructional models in public health higher education', BMC medical education, 14(1), p. 181. Available at: 
https://bmcmededuc.biomedcentral.com/track/pdf/10.1186/1472-6920-14-181

(Accessed: 20 August 2019).

Gilboy, M.B., Heinerichs, S. and Pazzaglia, G. (2015) 'Enhancing student engagement using the flipped classroom', Journal of nutrition education and behavior, 47(1), pp. 109-114.

Hall, A. and DuFrene, D. (2016) 'Best practices for launching a flipped classroom', Business and Professional Communication Quarterly, 79(2), pp. 234-242.

Hao, Y. and Lee, K.S. (2016) 'Teaching in flipped classrooms: Exploring pre-service teachers' concerns', Computers in Human Behavior, 57, pp. 250-260.

HEA (2010) 'Student Engagement literature review'. Available at: https://www.heacademy.ac.uk/system/files/studentengagementliteraturereview 1.pd f (Accessed: 12 September 2018).

Herr, K. and Anderson, G.L. (2005) The action research dissertation: a guide for students and faculty. London: SAGE.

Herreid, C. F. and Schiller, N. (2013) 'Case studies and the flipped classroom', Journal of College Science Teaching, 42(5), pp. 62-66.

Hew, K.F. and Cheung, W.S. (2012) Student participation in online discussions: Challenges, solutions, and future research. New York: Springer.

Heyborne, W.H. and Perrett, J.J. (2016) 'To flip or not to flip? Analysis of a flipped classroom pedagogy in a general biology course', Journal of College Science Teaching, 45(4), pp. 31-37.

Hine, G.S. (2013) 'The importance of action research in teacher education programs', Issues in Educational Research, 23(2), pp. 151-163. 
Huang, Y.N. and Hong, Z.R. (2016) 'The effects of a flipped English classroom intervention on students' information and communication technology and English reading comprehension', Educational Technology Research and Development, 64(2), pp. 175-193.

James, A.J., Chin, C.K.H. and Williams, B.R. (2014) 'Using the flipped classroom to improve student engagement and to prepare graduates to meet maritime industry requirements: a focus on maritime education', WMU Journal of Maritime Affairs, 13(2), pp. 331-343.

James, P. (1998) 'Progressive development of deep learning skills through undergraduate and postgraduate dissertations', Educational Studies, 24, pp. 95-105.

Kember, D. (2000) Action learning and action research: improving the quality of teaching and learning. London; Sterling, Va: Kogan Page.

Kemmis, S. (2009) 'Action research as a practice-based practice', Educational Action Research, 17(3), pp. 463-474.

Kurt, G. (2017) 'Implementing the flipped classroom in teacher education: evidence from Turkey', Journal of Educational Technology, 20(1), pp. 211-221.

Lage, M., Platt, G. and Treglia, M. (2000) 'Inverting the classroom: A gateway to creating an inclusive learning environment', The Journal of Economic Education, 31(1), pp. 30-43.

Lavelle, E. (2009) 'Writing through college: Self-efficacy and instruction', pp. 415-22, in: Beard, R., Myhill, D., Nystrand, M. and Riley, J. (eds.) The SAGE handbook of writing development. Los Angeles, Calif; London: Sage.

Lea, M. and Street, B. (1998) 'Student writing in higher education: an academic literacies approach', Studies in Higher Education, 23(2), pp. 157-172. 
Lewin, K. (1946) 'Action research and minority problems', Journal of Social Issues, 2(4), pp. 34-46.

Lillis, T. (2006) 'Moving towards an academic literacies pedagogy: dialogues of participation', pp. 30-45, in: Ganobscik-Williams, L. (ed.) Teaching academic writing in UK higher education: Theories, practices and models. Basingstoke: Palgrave MacMillan.

Markett, C., Sánchez, I.A., Weber, S. and Tangney, B. (2006) 'Using short message service to encourage interactivity in the classroom', Computers and Education, 46(3), pp. 280-293.

Mertens, D. M. (2015) Research and evaluation in education and psychology: Integrating diversity with quantitative, qualitative, and mixed methods (4th ed.). Los Angeles: SAGE.

Moran, K. and Milsom, A. (2015) 'The flipped classroom in counselor education', Counselor Education and Supervision, 54(1), pp. 32-43.

Morton-Cooper, A. (2000) Action research in health care. Malden, MA; Oxford: Blackwell Science.

Nematollahi, S., St John, P.A. and Adamas-Rappaport, W.J. (2015) 'Lessons learned with a flipped classroom', Medical Education, 49(11), p. 1143.

Norton, L. (2009) Action research in teaching and learning: a practical guide to conducting pedagogical research in universities. New York; London: Routledge.

O'Flaherty, J. and Phillips, C. (2015) 'The use of flipped classrooms in higher education: A scoping review', The Internet and Higher Education, 25, pp. 85-95.

Orr, S. (2005) 'Transparent opacity: assessment in the inclusive academy', pp. 175-187, in: Rust, C. (ed.) Improving student learning: Diversity and inclusivity. Oxford: The Oxford Centre for Staff and Learning Development. 
Perrett, G. (2003) 'Teacher development through action research: a case study in focused action research', Australian Journal of Teacher Education, 27(2), pp. 1-10.

Pienta, N.J. (2016) 'A “flipped classroom” reality check', Journal of Chemical Education, 93(1), pp. 1.

Pine, G.J. (2009) Teacher action research: building knowledge democracies. Los Angeles, Calif.; London: SAGE.

Sahin, A., Cavlazoglu, B. and Zeytuncu, Y.E. (2015) 'Flipping a college calculus course: a case study', Journal of Educational Technology and Society, 18(3), pp. 142-152.

Schlairet, M.C., Green, R. and Benton, M.J. (2014) 'The flipped classroom: strategies for an undergraduate nursing course', Nurse Educator, 39(6), pp. 321-325.

Schmidt, S.M.P. and Ralph, D.L. (2016) 'The flipped classroom: a twist on teaching', Contemporary Issues in Education Research, 9(1), pp. 1-6.

Schwartz, T.A. (2014) 'Flipping the statistics classroom in nursing education', The Journal of Nursing Education, 53(4), pp. 199-206.

Slomanson, W.R. (2014) 'Blended learning: a flipped classroom experiment', Journal of Legal Education, 64(1), pp. 93-102.

Smidt, J. (2009), 'Developing discourse roles and positionings - An ecological theory of writing development', pp. 117-125, in: Beard, R., Myhill, D., Nystrand, M. and Riley, J. (eds.) The SAGE handbook of writing development. Los Angeles, Calif; London: Sage.

Staker, H. and Horn, M. B. (2012) 'Classifying K-12 blended learning'. Available at: http://www.innosightinstitute.org/innosight/wp-content/uploads/2012/05/ClassifyingK-12-blended-learning2.pdf (Accessed: 31 January 2018). 
Strayer, J. (2007) The effects of the classroom flip on the learning environment: $A$ comparison of learning activity in a traditional classroom and a flip classroom that used an intelligent tutoring system. Unpublished PhD thesis. The Ohio State University, Columbus.

Teo, T. (2013) Handbook of quantitative methods for educational research. Rotterdam: Sense Publishers.

Vaughan, M. and Burnaford, G. (2016) 'Action research in graduate teacher education: A review of the literature 2000-2015', Educational Action Research, 24(2), pp. 280299.

Wagner, S. (2016) 'Peer feedback: Moving from assessment of learning to assessment for learning', Journal of Learning Development in Higher Education, Special Edition: Academic Peer Learning, Part Two, April, pp. 1-15.

Wang, Y. and Qi, G.Y. (2018) 'Mastery-based language learning outside class: Learning support in flipped classrooms', Language, Learning and Technology, 22(2), pp. 5074.

Wasserman, N.H., Quint, C., Norris, S.A. and Carr, T. (2017) 'Exploring flipped classroom instruction in Calculus III', International Journal of Science and Mathematics Education, 15(3), pp. 545-568.

Wei, C., and Chen, N. (2012) 'A model for social presence in online classrooms', Educational Technology Research and Development, 60(3), pp. 529-545.

Xiao, L.D., Kelton, M. and Paterson, J. (2012) 'Critical action research applied in clinical placement development in aged care facilities', Nursing Inquiry, 19(4), pp. 322-333.

Zainuddin, Z. and Halili, S.H. (2016) 'Flipped classroom research and trends from different fields of study', International Review of Research in Open and Distance Learning, 17(3), pp. 467-84. 
Zuber, W.J. (2016) 'The flipped classroom, a review of the literature', Industrial and Commercial Training, 48(2), pp. 97-103.

\section{Author details}

Jessica Clare Hancock is a lecturer in Educational Development at City, University of London. Prior to this, she worked as a learning developer at several UK HEls, and she is a current member of the Learn Higher working group. Her research interests centre around identity, especially gender identities, in a variety of contexts, including in academic writing. 